\title{
Church as an Eschatological Community and Worship Service in the Post-Covid-19 Era
}

\author{
Tony Salurante ${ }^{1}$, David Kristanto ${ }^{2}$ \\ \{tony.salurante@sttsetia.ac.id ${ }^{1}$, davidkristanto@sttsetia.ac.id²\} \\ Sekolah Tinggi Teologi Injili Arastamar (SETIA) Jakarta ${ }^{1,2}$
}

\begin{abstract}
Covid-19 makes the church becomes what Heidi Campbell called "The Distanced Church." Campbell argues further that the adjective "distanced" here should refer to physical distancing but not social distancing because the desire for communion and fellowship among the church members has never ceased. Since they are unable to gather physically, the church leaders opt for technology to enable their members to socialize without any physical interactions. That situation explains why the legitimacy of online worship services is often discussed among theologians and religious leaders since the beginning of the Covid-19 pandemic. It has also been argued that the online worship should be extended to the post-Covid-19-era. Using systematic theology as a research method, this paper argues that the role of the church as an eschatological community should be properly taken into consideration in the discussions. As an eschatological community, the Church is called to believe in God's restorative work over his creation and partake in that restorative work. That theological position implies that the church should anticipate the postpandemic time when the members would be able to gather on-site. Even though online worship is a legitimate way of worship, on-site worship, accompanied by social unity and physical unity, is the fuller expression of Christian worship. Furthermore, this paper suggests the house church concept for the revitalization of Christian worship in the post-Covid-19. This concept combines online and on-site mode of worship in a house with two or three families as the gathered members.
\end{abstract}

Keywords: Church; Christianity; Ecclesiology; Post-Covid-19 Era; Religion; Worship

\section{Introduction}

Heidi Campbell explains the present situation of the church as the "distanced church." It is a situation where the church members are eager to have social interaction yet are forced to distance themselves physically from one another (Campbell 2020, p. 4). Following that position, the term "physical distancing" is preferable to "social distancing." In the Indonesian context, the physical distancing policy was issued on $15^{\text {th }}$ March 2020. Through that policy, the government obliged the citizens to study, work, and worship from home. At first, it was quite difficult to implement the policy. Some religious members who tended toward 
"extremism" tried to oppose the policy, yet in the end, all religious communities were forced by the situation to comply (Sukamto and Panca Parulian 2021, p. 276).

That situation led the church leaders to opt for technology. At first, it was unnatural for the church to worship online, and many people prefer to worship on-site if there were possibilities to do so. In the beginning phase, the transition from on-site worship to online worship during the Covid-19 pandemic could be seen as an "imposition," rather than a natural transition. However, after a year of worship online (2020-2021), many church leaders realize the importance of using technology for religious causes. Online worship is understood by the church no longer as an imposition but as a new strategy (Singarimbun 2021, p. 96). Many among the church leaders realize that "moving online" could open many outreach opportunities and might influence a larger audience (Campbell and Shepherd 2021, p. 8). Due to the huge advantage that the church could gain through the online network, it has been argued that online worship should extend even to the post-Covid-19 era (Tambunan 2020, p. 154). Even though it is important to consider the advantage and disadvantages of being an online church, discussions revolving around the topic should not be based on pragmatic reasons alone. The church leaders should mainly reflect theologically upon the topic to have a solid theological basis for them to take the next step, which is how to lead the church and to conduct worship properly in the post-Covid-19 era.

This paper argues that the role of the church as an eschatological community should be emphasized when imagining the post-pandemic church. As an eschatological community, the church is a group of people who are united in one hope, which is the restoration of all creation through God's redemptive work. The pandemic would not last forever, for there will be God's restoration of the world from the pandemic. After such a restoration, worshipping on-site will be possible, and physical distancing might no longer be necessary. Under that condition, worshipping online would no longer be a necessity but an option.

The research method used in this paper is systematic theology. According to Smith, systematic theology is a study of what the Bible teaches on a particular theme or topic (Smith 2019 , p. 139). This paper will imagine the post-pandemic church from the lens of the doctrine of the last things (eschatology) and how such a theological imagination could contribute to revitalizing worship in the post-Covid-19 era. Toward that purpose, this paper will be written under this sequence: first, imagining the post-pandemic church; second, eschatological hope and post-pandemic church; third, revitalizing worship in the post-pandemic church.

\section{Results and Discussion}

\subsection{Imagining the Post-Pandemic Church}

Theological imagination is a very important task for the church, for there would be no Christian hope if the ability to imagine is taken away from the church members. Theological imagination is not a mere intellectual activity but a theological vision of the welfare of human beings based on the Bible. It is not an invitation to enter an imaginative world or a dream world but refers to what Alister McGrath called in the Latin word "imaginarium" in the Christian tradition. It refers to a transformed capacity to see reality on a deeper level that might allow people to appreciate the creation better (McGrath 2017, p. 43).

Theological imagination is always a combined product of a particular Christian tradition and a Christian's personal experience. Ecclesiology itself is a theological imagination. It does not refer to a particular local church, but it imagines the church in her most ideal shape. In this 
regard, eschatology is indispensable. One cannot imagine an ideal condition of the church without thinking forward to the glorious future promised by God. Thus, ecclesiological imagination should be put in dialogue with eschatological imagination that depicts the divine plan for the whole cosmos from the creation to the new creation that encourages the church to serve God and his beloved creation (MacDougall 2015, pp. 2-3). That is a crucial role that theology could play, especially in the pandemic situation, which is to encourage people to appreciate the world as God's beautiful creation. Even though the picture of the postpandemic church remains vague to us today, engaging in a theological imagination of the post-

pandemic church is a very important task. It will help the people to reflect upon the ideal condition of the church that might affect how do they live as Christians today.

\subsection{Eschatological Hope and Post-Pandemic Church}

As mentioned earlier, eschatology would play an important role in the task of imagining the post-pandemic church. Even though Christians should hope that God would restore the church in the post-pandemic era, it is important to highlight that Christian eschatological hope is not limited to the church but extends to the restoration of the whole cosmos. Abraham Kuyper in his speech entitled "The Blurring of the Boundaries" called for his audience to see through the vision of "palingenesis" (from Greek word palingenesia). He deliberately used the term, for it refers to both personal rebirth as it is in Titus 3:5 and the rebirth of all creation in Matthew 19:28 (Kuyper 1998, p. 398). Kuyper's position shows how Christian hope for personal salvation and the restoration of all creation is interrelated. This vision does not deny the fact that there is sin, suffering, and evil in the world, but this vision shows the hope for the world to be completely restored by God according to His divine plan.

It is also important to see how this vision of restoration has relevance to the church today. Because the eschatological hope is extended to the restoration of all cosmos, Christians should actively participate in God's restorative works. According to Bartholomew, Kuyper's palingenesis could bridge "deep Christocentric spirituality" and "cultural engagement" (Bartholomew 2017, p. 318). To be spiritual is not to flee or be ignorant to what is going on in the world, but to care and to participate in the activities that might bring restoration and healing to God's creation. Herman Bavinck encourages Christians to be the agent of restoration in all spheres of life such as art, family, science, government, and the broader society (Bavinck 2011, 641). As the physical distancing policy and the restriction of public activities might be less strict in the post-Covid-19 era, the church should seek new opportunities to serve as God's agent of healing and restoration in the world.

That same spirit of restoration should also be expressed through the church's worship service. During the pandemic, research done by Indonesia Preaching Ministry has recorded only around $20 \%$ of the church members had faithfully followed the online worship service from the beginning to the end (Harmadi and Budiatman 2021, p. 144). Spiritually speaking, that condition is far from healthy. The church should not assume that the condition will automatically improve in the post-Covid-19 era, rather, a serious attempt to revitalize the worship service motivated by the restorative eschatological hope should begin.

\subsection{Revitalizing Worship in the Post-Pandemic Church}

There might be possibilities to worship on-site for the post-pandemic church, yet it would still be under different conditions than in the pandemic time. Some churches might still have to conduct hybrid (both online and on-site) worship because of some members who are unable 
to attend on-site worship due to health concerns. And those who are healthy and able to worship on-site might still have to care for the health of the community by complying with the health protocol advised by the local government. Hilton Scott has proposed an interesting proposal when imagining worship in the post-lockdown context. He proposes to reinterpret African notion of "ubuntu" which means "I am, because we are" to "I am safe because we are safe," or "I am healthy because we are healthy." He also argues that the health protocol should undergo a process of ritualization so it would be an integral part of the worship service not just considered as additional (Scott 2020, 4-5). The possibility of returning to on-site worship in the post-pandemic time does not guarantee a monolithic decision among the church leaders. There would be at least three decisions: continue online, on-site, and hybrid (both online and on-site) worship. The decision on whether the church chooses to do on-site worship as soon as possible or not is determined by their understanding of, "how embodied is the body of Christ" (Bare 2020, p. 36).

Jimmy Lizardo has argued that the house church concept could help to revitalize worship during the pandemic (Lizardo 2020, p. 92). In the post-pandemic church, the concept of house church might also be promisingly relevant. This might enable those who prefer online worship to experience an "embodied" fellowship as well. The other members of the house church might be the family, or it can also get more members by inviting one or two other families to attend online worship together at a house. This model might strengthen discipleship between the families (Mermilliod 2020, p. 11); furthermore, this concept does not threaten the unity of the church, but could draw the image of the church as a family of God, and could be a reminder of how a local church consists actually of families (Brandner 2019, p. 219).

\section{Conclusion}

It is important for the church today to theologically imagine the post-pandemic church. Even though the picture of such a church remains vague for now, theological imagination could evoke the ideal shape of the church that might motivate today's church to be better. Christian eschatology that stresses God's restorative works upon His people and the whole creation should be the ground of the church's theological imagination. Without a strong eschatological hope, the church in the pandemic time would lose her direction and fall into despair. When imagining the post-pandemic church, it is important to not assume that the church would automatically be better. The eschatological hope of restoration should be the motivation for the church to engage in God's restorative works in all spheres of life, including in the area of church worship. The church should seek how to renew and improve the quality of Christian worship in the post-pandemic era. One suggestion in this paper is to revitalize worship through practicing house church fellowships; thus, the church members who are unable to do on-site worship due to various reasons might still experience "embodied" fellowship with others. This concept does not threaten the church unity, for the Bible also depicts the church as the family of God, and the local church consists actually of families.

\section{Acknowledgments}

This research is sponsored by Sekolah Tinggi Teologi Injili Arastamar (SETIA) Jakarta. The authors are thankful for the generous support. 


\section{References}

[1] Bare, Daniel R. 2020. "How Embodied Is 'the Body of Christ?' COVID-19 and Christian Corporeality." Pp. 36-38 in Religion in Quarantine: The Future of Religion in a Post-Pandemic World, edited by H. A. Campbell. Texas: Digital Religion Publications.

[2] Bartholomew, Craig G. 2017. Contours of the Kuyperian Tradition. Illinois: IVP Academic.

[3] Bavinck, Herman. 2011. Reformed Dogmatics: Abridged in One Volume. edited by J. Bolt. Grand Rapids: Baker Academic.

[4] Brandner, Tobias. 2019. "The Church as Family: Strengths and Dangers of the Family Paradigm of Christianity in Chinese Contexts." Theology Today 76(3):217-23.

[5] Campbell, Heidi A., ed. 2020. The Distanced Church: Reflections on Doing Church Online. Texas: Digital Religion Publications.

[6] Campbell, Heidi A. and Troy Shepherd. 2021. What Should Post-Pandemic Religion Look Like? 10 Trends Religious Groups Need to Understand to Survive and Thrive in the Next Decade. Texas: Digital Religion Publications.

[7] Harmadi, Mariani and Adi Dharma Budiatman. 2021. "Pergeseran Perspektif Teologi Penggembalaan Dengan Layanan Virtual Pada Masa Pandemi Sekarang Dan Nanti." Jurnal Teologi Berita Hidup 3(2):137-49.

[8] Kuyper, Abraham. 1998. "The Blurring of the Boundaries (1892)." Pp. 363-402 in Abraham Kuyper: A Centennial Reader, edited by J. D. Bratt. Grand Rapids: Wm. B. Eerdmans.

[9] Lizardo, Jimmy. 2020. "Penerapan Gereja Rumah Sebagai Cikal Bakal Gereja Virtual.” Jurnal Teologi Rahmat 6(2):96.

[10] MacDougall, Scott. 2015. More than Communion: Imagining an Eschatological Ecclesiology. London: Bloomsbury.

[11] McGrath, Alister E. 2017. Re-Imagining Nature: The Promise of A Christian Natural Theology. Malden: Wiley-Blackwell.

[12] Mermilliod, Edward P. 2020. "A Synthesis of Academic Research Related to ChurchBased Family Ministry." Christian Education Journal.

[13] Scott, Hilton R. 2020. "Worship in a Post-Lockdown Context: A Ritual-Liturgical Perspective." HTS Teologiese Studies / Theological Studies 76(1):1-8.

[14] Singarimbun, Kartika. 2021. "E-Church as a Virtual Service Communities During COVID-19 Pandemics.” Jurnal Komunikasi Ikatan Sarjana Komunikasi Indonesia 6(1):96-106.

[15] Smith, K. G. 2019. Writing \& Research: A Guide for Theological Students. Carlisle: Langham Global Library.

[16] Sukamto, Amos and S. Panca Parulian. 2021. "Religious Community Responses to the Public Policy of the Indonesian Government Related to the Covid-19 Pandemic." Journal of Law, Religion and State 8(2-3):273-83.

[17] Tambunan, Fernando. 2020. "Analisis Dasar Teologi Terhadap Pelaksanaan Ibadah Online Pascapandemi Covid-19." EPIGRAPHE: Jurnal Teologi Dan Pelayanan Kristiani 4(2):154-69. 